\title{
Nephrotic syndrome in hepatosplenic schistosomiasis mansoni
}

Síndrome nefrótica na esquistossomose mansônica hepatoesplênica

José Roberto Lambertucci ${ }^{1}$, Alba Otoni ${ }^{1}$ and Marlene Antônia dos Reis ${ }^{2}$

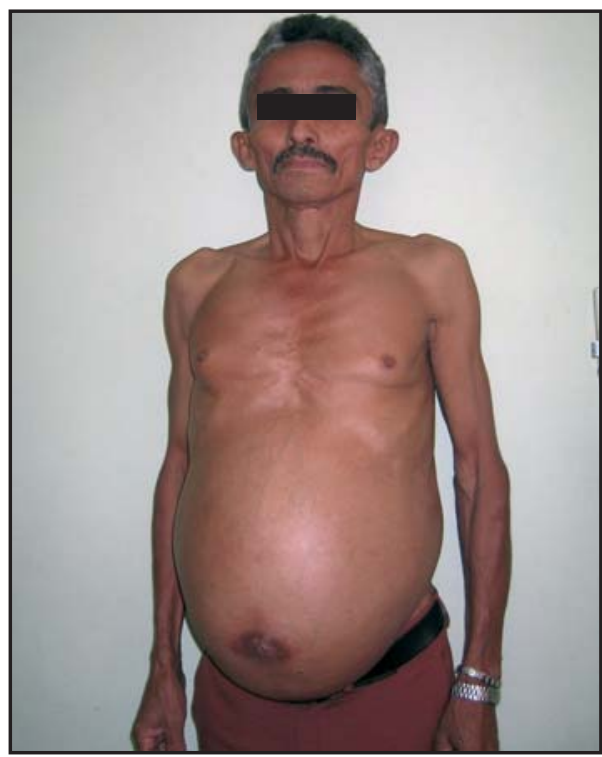

A

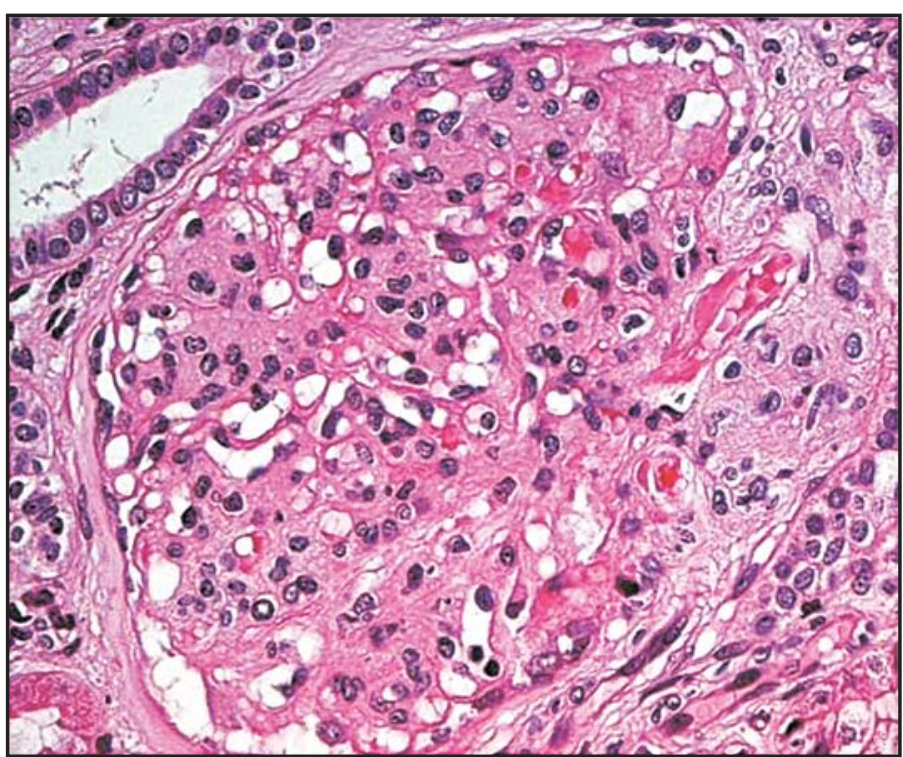

B

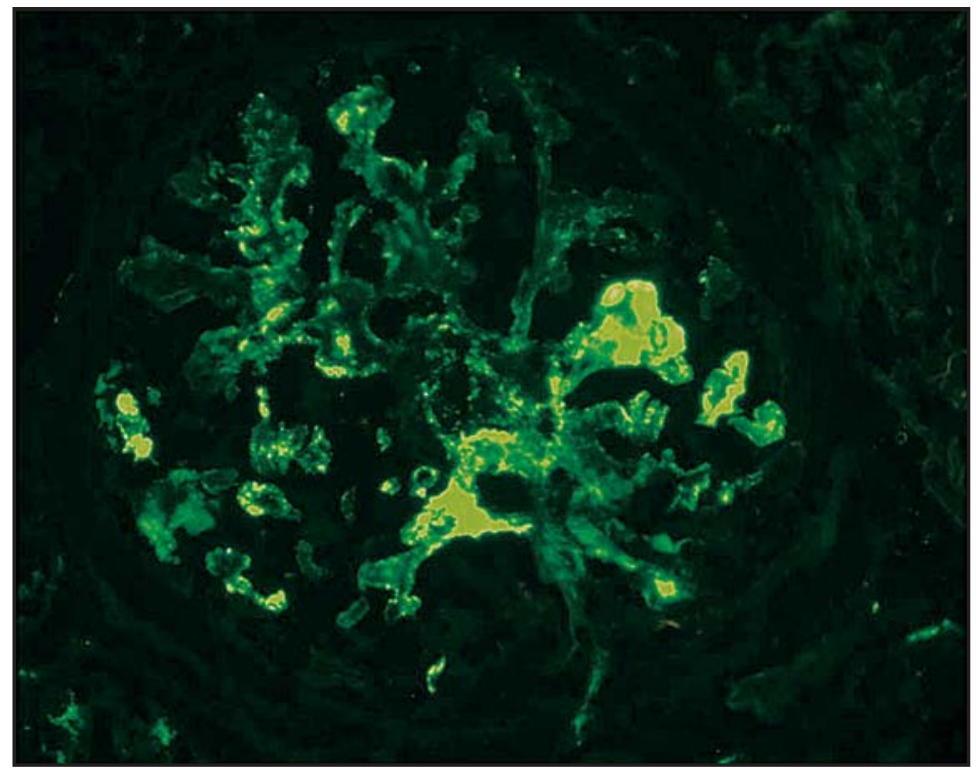

C

1. Serviço de Doenças Infecciosas e Parasitárias, Faculdade de Medicina, Universidade Federal de Minas Gerais, Belo Horizonte, MG. 2. Disciplina de Patologia Geral, Universidade Federal do Triângulo Mineiro, Uberaba, MG.

Address to: Dr. José Roberto Lambertucci. Faculdade de Medicina/UFMG. Av. Alfredo Balena 190, 30130-100 Belo Horizonte, MG, Brazil.

e-mail: lamber@uai.com.br

Recebido em: 12/06/2007

Aceito em: 17/07/2007 
A 51-year-old man sought the hospital for consultation regarding ascites that was refractory to standard treatment with diuretics. Seventeen years earlier he had been diagnosed with hepatosplenic schistosomiasis mansoni. This had been confirmed by ultrasound, which showed periportal thickening characteristic of schistosomiasis. On that occasion, he was treated with oxamniquine and was then followed up in his hometown in the northeast of Minas Gerais, Brazil. His renal function was normal when he was first seen in 1990. In 2004, he developed ascites and was found to have proteinuria in a routine urine test. In 2006, a renal function review revealed: serum creatinine of $2.0 \mathrm{mg} / \mathrm{dl}$; blood urea nitrogen (BUN) of $88 \mathrm{mg} / \mathrm{dl}$; creatinine clearance of $70 \mathrm{ml} / \mathrm{min}$; and 24-hour proteinuria of $4.7 \mathrm{~g}$. In Figure $\mathrm{A}$, the patient appears emaciated, and presents voluminous ascites. A kidney biopsy was performed, which via optical microscopy showed type I membranoproliferative glomerulonephritis, with duplication of the basal membrane and cell proliferation (Figure B). Peripheral glomerular subendothelial deposits of $\mathrm{IgG}$, IgM and $\mathrm{C} 3$ complement were identified by a direct fluorescent technique (Figure C). Electron microscopy confirmed the presence of subendothelial electron-dense deposits in the capillary loops of the glomeruli. This is the case of a patient who developed nephrotic syndrome during the course of hepatosplenic schistosomiasis.

0 paciente, de 51 anos, procurou o hospital para propedêutica de ascite refratária ao tratamento com diuréticos. Dezessete anos antes ele teve o diagnóstico de esquistossomose mansônica hepatoesplênica confirmado pelo ultra-som que revelou espessamento periportal característico da esquistossomose. Na ocasião, ele foi tratado com a oxamniquine e acompanhado em sua cidade natal no nordeste de Minas Gerais, Brasil. A função renal era normal, quando ele foi avaliado em 1990. Em 2004, o paciente desenvolveu ascite e havia proteinúria em exame rotineiro de urina. Em 2006, uma revisão da função renal mostrou: creatinina sérica: $2,0 \mathrm{mg} / \mathrm{dl}$; uréia: $88 \mathrm{mg} / \mathrm{dl}$; depuração de creatinina de $70 \mathrm{ml} / \mathrm{min}$; e proteinúria de 24 horas de $4,7 \mathrm{~g}$. Na Figura A, o paciente parece emaciado e com ascite volumosa. Realizou-se a biópsia renal que evidenciou glomerulonefrite membranoproliferativa tipo I, com duplicação da membrana basal e proliferação de células, sob a microscopia de luz (Figura B) e, pela técnica de imunofluorescência direta, observaramse depósitos glomerulares periféricos, subendoteliais de $\mathrm{IgG}$, IgM e complemento (C3) (Figura C). A microscopia eletrônica confirmou a presença de depósitos elétron densos subendoteliais nas alças capilares dos glomérulos. Este é o caso de paciente que desenvolveu síndrome nefrótica, durante a evolução da esquistossomose hepatoesplênica.

\section{REFERENCES}

1. Barsoum R. The changing face of schistosomal glomerulopathy. Kidney International 66: 2472-2484, 2004.

2. Lambertucci JR, Godoy P, Bambirra EA, Neves J, Tafury WL, Leite VH. Renal involvement in Salmonella-Schistosoma mansoni association. Revista da Sociedade Brasileira de Medicina Tropical 20: 83-89, 1987.

3. Lambertucci JR, Serufo JC, Gerspacher-Lara R, Rayes AA, Teixeira R, Nobre V, Antunes CM. Schistosoma mansoni: assessment of morbidity before and after control. Acta Tropica 23: 101-109, 2000. 